Article

\title{
The Potential of Oxygenates to Increase the Risk of Exposure to Polycyclic Aromatic Hydrocarbons through Groundwater Contamination
}

\author{
Michael O. Eze ${ }^{1,2, *(D)}$ and Simon C. George ${ }^{2}$ (D) \\ 1 Department of Genomic and Applied Microbiology, Georg-August University of Goettingen, \\ 37077 Goettingen, Germany \\ 2 School of Natural Sciences, Macquarie University, Sydney, NSW 2109, Australia; \\ simon.george@mq.edu.au \\ * Correspondence: meze@gwdg.de
}

Citation: Eze, M.O.; George, S.C. The Potential of Oxygenates to Increase the Risk of Exposure to Polycyclic Aromatic Hydrocarbons through Groundwater Contamination. Water 2022, 14, 739. https://doi.org/ 10.3390/w14050739

Academic Editor: Dimitrios

E. Alexakis

Received: 4 February 2022

Accepted: 24 February 2022

Published: 25 February 2022

Publisher's Note: MDPI stays neutral with regard to jurisdictional claims in published maps and institutional affiliations.

Copyright: (c) 2022 by the authors. Licensee MDPI, Basel, Switzerland. This article is an open access article distributed under the terms and conditions of the Creative Commons Attribution (CC BY) license (https:/ / creativecommons.org/licenses/by/ $4.0 /)$.

\begin{abstract}
The Clean Air Act (42 U.S. Code $§ 7401$ ) is one of the United States of America's most influential environmental laws. Under the Clean Air Act Amendments of 1990, oxygen-containing organic compounds must be added to some fossil fuels with the goal of combating $\mathrm{CO}_{2}$ and particulate emissions. However, one major implication is the effect of co-solvency on the leaching potentials of polycyclic aromatic hydrocarbons (PAHs) into groundwater. Our research investigated this effect on three groups of recalcitrant PAHs that are present in diesel fuel. Our results reveal that ethanol addition enhances the leaching potentials of these otherwise hydrophobic contaminants, with $10 \%$ ethanol (E10) resulting in elution of all the PAHs studied. While 5\% ethanol addition to diesel fuel resulted in the elution of an average of $2.5 \%$ of all the trimethylnaphthalenes and $6.0 \%$ of the $\mathrm{C}_{2}$ alkylphenanthrenes present in diesel fuel, $10 \%$ ethanol addition led to the elution of more than $80 \%$ of each of the studied trimethylnaphthalene peaks and more than $70 \%$ of each of the studied $\mathrm{C}_{2}$ alkylphenanthrene peaks present in diesel fuel. In view of the known mutagenic and carcinogenic risks associated with exposure to PAHs through groundwater contamination, our study highlights the need for energy scientists to carefully consider the environmental and health implications of ethanolblended innovations holistically. It is not enough to save the atmosphere but ruin the hydrosphere and most importantly, human health.
\end{abstract}

Keywords: ethanol-blended fuels; leaching; polycyclic aromatic hydrocarbons; groundwater contamination; toxicity

\section{Introduction}

The United States of America's (USA's) Clean Air Act Amendments of 1990 require that oxygen-containing organic compounds such as methyl-tertiary-butyl ether (MTBE) or ethanol must be added to gasoline in some areas of the USA to reduce air pollution [1]. Since then, the use of ethanol has increased, with many countries formulating various ethanol-fuel mixtures. The percentage of ethanol in the ethanol-fuel mixture is designated by a number following the letter "E". For example, "E20" refers to an ethanol-blended petroleum fuel containing $20 \%$ of ethanol and $80 \%$ petroleum fuel. Gasoline blends of E10 or less are in use in more than 20 countries around the world. In the USA, ethanol represented $10 \%$ of the gasoline fuel supply from domestic sources in 2011 [2]. Since 2007, the mandatory blend of gasoline in Brazil is $25 \%$ ethanol and $75 \%$ gasoline $[3,4]$, and in 2016, ethanol represented $27 \%$ of the gasoline blend sold to consumers in Brazil [5]. In many parts of Europe, the optional blends range from E5 to E85, while Australia and New Zealand both have E10 as their optional blend. While ethanol-diesel fuel mixtures are less common than their gasoline counterparts, blends of up to $15 \%$ ethanol in diesel fuel, 
known as e-diesel, can and have been used in compression ignition engines. Ethanol-diesel mixtures range from E5 to E85, with E10 being the most common.

The innovation of adding ethanol to gasoline aimed at reducing the emission of $\mathrm{CO}_{2}$ and particulate matter [6-8], but it is not without attendant consequences. One major implication is the effect of co-solvency on the leaching potentials [9] and biodegradation [10] of petroleum hydrocarbons, with most concern being focused on monoaromatic hydrocarbons such as benzene, toluene, ethylbenzene, and xylene (BTEX). While BTEX compounds have been the subject of considerable research within the recent decades [10-12], little is known about the impact of ethanol-induced co-solvency on the leaching potentials of high molecular weight polycyclic aromatic hydrocarbons. This is of great concern due to their toxicity and persistence in the environment. For example, Snape, et al. [13] in a study of fuel spills in Antarctica showed that the relatively aqueous insoluble dimethylnaphthalenes were not degraded. Similarly, Wang et al. [14] found increasing resistance to biodegradation with increasing alkylation in the $\mathrm{C}_{0}-\mathrm{C}_{4}$ alkylnaphthalenes. Compounding this problem is the fact that ethanol addition often results in the depletion of electron acceptors and nutrients owing to preferential degradation of ethanol by soil and water microbes [11,15]. Although large-scale aquatic spills attract much public attention, the vast majority of spills globally are of moderate scale (from $100 \mathrm{~m}^{3}$ to $1000 \mathrm{~m}^{3}$ ), and they occurred on land, thereby serving as potential sources of groundwater contamination [16]. Sadly, groundwater contamination by these compounds from above-ground and underground fuel spills has been of growing concern in recent years. Ugochukwu and Ochonogor [17] reported groundwater contamination with human health risk exposure due to a diesel spill from a telecom base station in Jos, a Nigerian city. Similarly, the presence of petrochemical storage tanks was responsible for groundwater PAH contamination in an industrialized area in India [18]. The frequency of spills varies across different regions of the world. In the Niger Delta region of Nigeria, for example, it was estimated that more than 9000 spills occurred between 2006 and 2015, with an average volume of 115,000 barrels annually [19]. This portends danger for humans owing to their carcinogenicity. For example, benzene and naphthalene are classified as Group 1 and Group 2B carcinogens, respectively, by the International Agency for Research on Cancer [20-22]. Similarly, animal studies implicated dimethylphenanthrenes as tumourinitiating [23] and methylpyrenes as potentially carcinogenic [24-26]. The ease of migration of these contaminants to groundwater is related to the addition of oxygenates to these fossil fuels, especially ethanol. This is expected to be even more the case for gasoline, owing to the higher proportion of lower molecular weight (and more aqueous soluble) aromatic hydrocarbons such as benzene, alkylbenzenes, and alkylnaphthalenes in gasoline than in diesel. Interestingly, studies have shown that fossil fuels such as reformulated gasoline can be made to maintain high octane rating (even with a reduction in aromatic hydrocarbon content) through various isomerization reactions using alkylation catalysts [27-29]. It is therefore imperative that the human and environmental impacts of ethanol addition, and by extension other oxygenates, be properly evaluated.

In view of this, our research investigated the effect of ethanol addition on the leaching potentials of three groups of recalcitrant and potentially carcinogenic PAHs present in diesel fuel. These are alkylnaphthalenes, alkylphenanthrenes, and alkylpyrenes, representing the bicyclic, tricyclic, and tetracyclic aromatic hydrocarbons, respectively.

\section{Materials and Methods}

\subsection{Leaching Columns}

The leaching method was documented in detail in Eze and George [30]. Ethanolblended diesel fuel $(5 \mathrm{~mL})$ was eluted through a $90 \mathrm{~cm} \times$ ID $13 \mathrm{~mm}$ sand column $(97.5 \%$ sand, $2.5 \%$ silt, and $0.02 \%$ clay), and the effects of ethanol addition on the movement of three groups of recalcitrant PAHs present in diesel fuel (trimethylnaphthalenes, dimethylphenanthrenes, and methylpyrenes) were investigated. An unblended diesel (E0) and two blends of ethanol-diesel mixtures (E5 and E10) were investigated. 
The leachate from the bottom of each column was collected in a beaker. Since the aqueous leachates contained diesel fuel hydrocarbons with ethanol as a co-solvent, repeated liquid-liquid extraction using dichloromethane (DCM) and a separating funnel was used to isolate the diesel fuel hydrocarbons from the aqueous leachates [31,32]. To enable proper comparison of relative abundances, the volume of solvent $(100 \mathrm{~mL})$ used during liquid-liquid extraction and the concentration procedure prior to gas chromatographymass spectrometry (GC-MS) were the same for each leachate. The concentration procedure involved the evaporation of excess DCM using a rotary evaporator followed by gentle nitrogen blowdown.

\subsection{Gas Chromatography-Mass Spectrometry Analysis of Leachates}

To assess the degree to which ethanol enhanced the leaching of aromatic hydrocarbons, the leachates from each column were analysed using GC-MS to determine their molecular compositions [33]. This was carried out using a Leco Pegasus 4D instrument (St. Joseph, MI, USA) in the Organic Geochemistry laboratory, Macquarie University, Sydney, according to the procedure of Flannery and George [34]. Analysis was on a two-dimensional gas chromatograph (modified Agilent 7890A (Santa Clara, CA, USA)) operating in one dimension, coupled to a Pegasus time-of-flight-mass spectrometer (GCxGC-ToFMS). The hydrocarbon leachates in DCM $(1 \mu \mathrm{L})$ were injected through a split/splitless injector operating at $310{ }^{\circ} \mathrm{C}$ in splitless mode onto a J\&W (Midland, TX, USA) DB5MS column (60 m $\times 0.25 \mathrm{~mm}$ i.d., $0.25 \mathrm{~mm}$ film thickness) coated with modified 5\% phenyl 95\% methyl silicone, with He as the carrier gas. The temperature programme was $40{ }^{\circ} \mathrm{C}(2 \mathrm{~min})$ to $310{ }^{\circ} \mathrm{C}$ at $4{ }^{\circ} \mathrm{C} / \mathrm{min}$, then held for $45 \mathrm{~min}$. Peak areas were integrated using LECO Chromatof software. The amount of leachate injection and the instrument response for each analysis run were held constant, enabling comparison of relative abundance using the peak areas.

\section{Results and Discussion}

\subsection{Effect of Ethanol on the Leaching of Polycyclic Aromatic Hydrocarbons}

Figure 1 shows partial mass chromatograms that are selective for the trimethylnaphthalenes (mass-to-charge ratio, $m / z$ 170), dimethylphenanthrenes and ethylphenanthrenes $(m / z 206)$, and methylpyrenes $(m / z 216)$ that were detected in the leachates from the E0, E5, and E10 columns. Similar observations were made with respect to aliphatic hydrocarbons and some aromatic hydrocarbons, as reported by Eze and George [30]. These three examples, however, give an overview of the effect of ethanol on the vertical migration of more complex polycyclic aromatic hydrocarbons, with potential negative impacts on human health through groundwater contamination.

As shown in Figure 1, ethanol addition enhanced the leaching potentials of otherwise hydrophobic contaminants. For example, none of the studied PAHs were detected in the E0 leachates. Low relative abundances of each of the three groups of PAH were detected in the E5 leachates. With the increase in the ethanol content of the diesel fuel of the E10 leachate, there was a considerable increase in the amount of PAHs eluted through the columns. This was expected since ethanol is a co-solvent, which consequently enhances the solubility of petroleum hydrocarbons in water. Thus, an increase in the percentage by volume of ethanol leads to an enhanced miscibility of these toxic organic compounds, and consequently their availability in underground water.

Evaluation of the areas of the chromatograms enabled determination of the percentages of the various polycyclic aromatic hydrocarbons in diesel fuel that were eluted by ethanol. For example, Figure 2 compares the relative abundance of the individual trimethylnaphthalenes (Figure $2 \mathrm{a}$ ) and $\mathrm{C}_{2}$ alkylphenanthrenes (dimethylphenanthrenes and ethylphenanthrenes) (Figure 2b) in the E5 and E10 leachates with their content in pure diesel. 
(a)
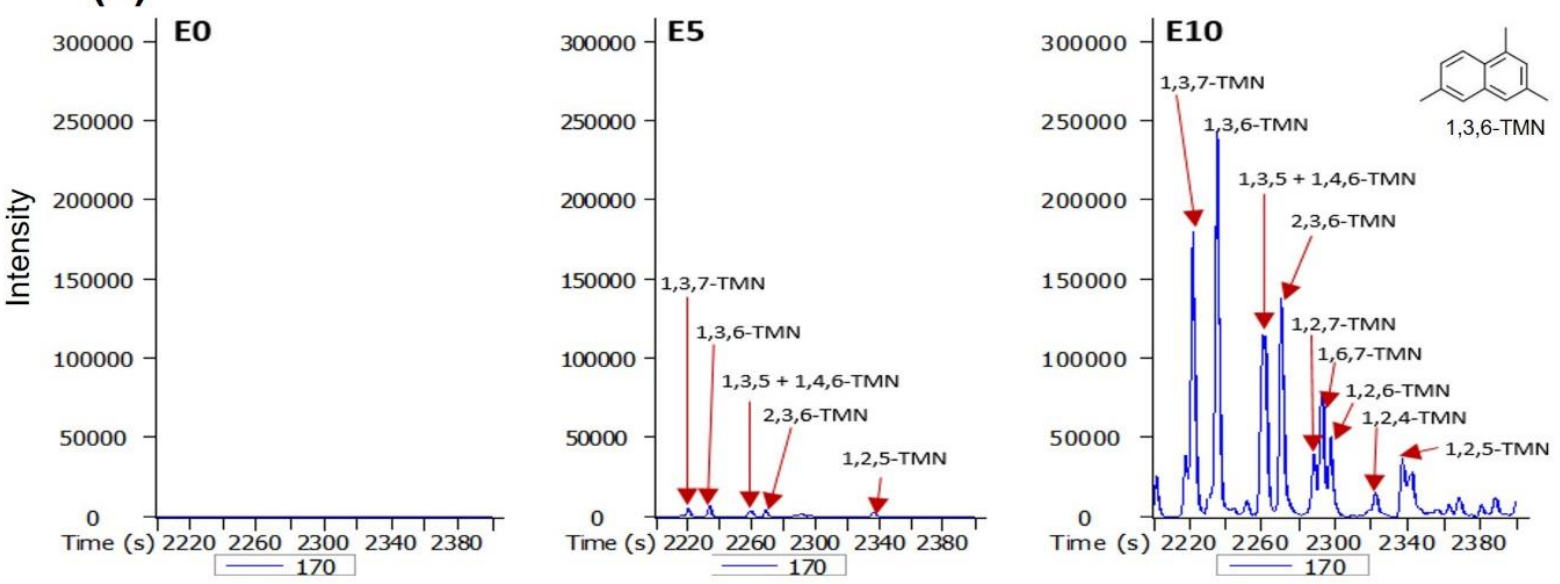

(b)
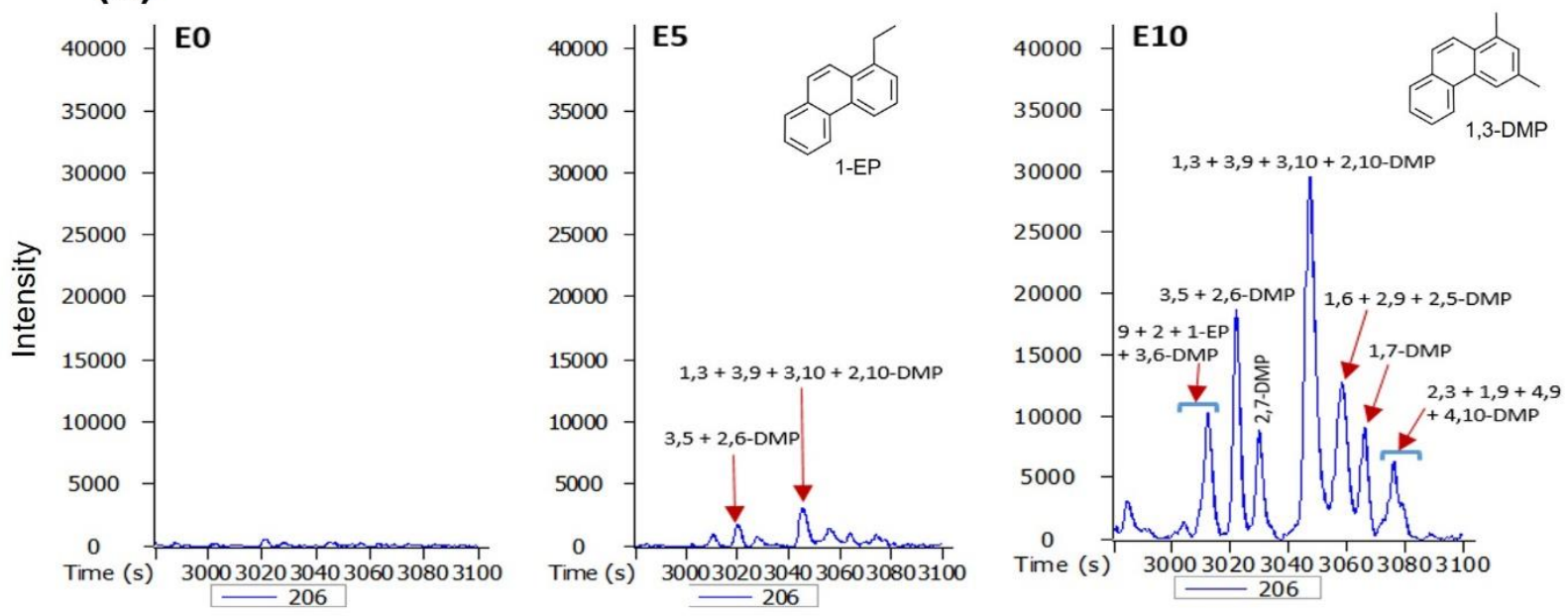

(c)

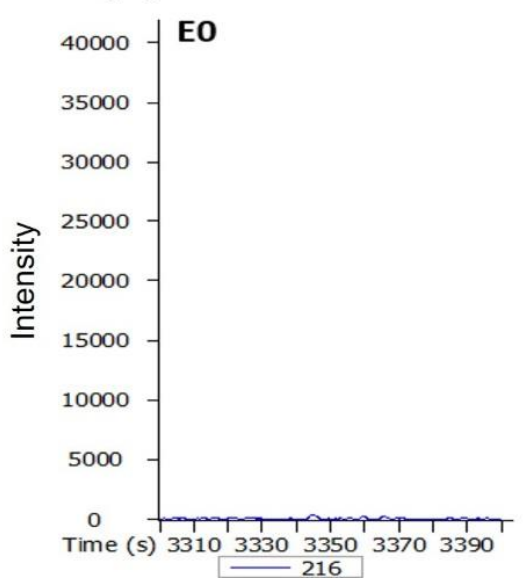

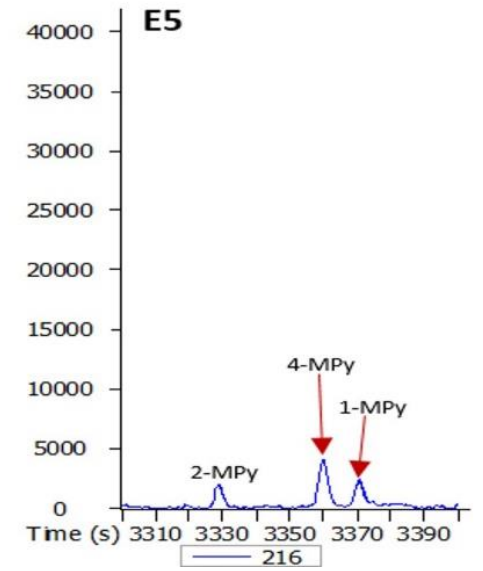

Figure 1. Partial (a) $m / z$ 170, (b) $m / z$ 206, and (c) $m / z 216$ mass chromatograms of the E0, E5, and E10 leachates, showing identification of the trimethylnaphthalenes (TMN), dimethylphenanthrenes (DMP) and ethylphenanthrenes (EP), and methylpyrenes (MPy), respectively. The detection of both DMP and EP at $m / z 206$ was due to their having the same molecular mass. Numbers denote the positions of alkylation. 
When the amounts of trimethylnaphthalenes and $C_{2}$ alkylphenanthrenes eluted by ethanol addition were compared with their respective amounts in pure diesel (Figure 2), it was seen that $10 \%$ ethanol addition eluted nearly all the trimethylnaphthalenes and $C_{2}$ alkylphenanthrenes that were present in diesel fuel. It was also observed that hydrocarbons with longer retention times such as 1,2,4-trimethylnaphthalene, 1,2,5-trimethylnaphthalene, and the co-eluting 2,3-, 1,9-, 4,9- and 4,10-dimethylphenanthrene peak were not detected in the E5 leachate (Figure 2; Table 1). These less mobile hydrocarbons were however eluted in the E10 leachates.

Analysis of the areas of the chromatograms further revealed that $5 \%$ ethanol addition eluted an average of $2.5 \%$ of all the trimethylnaphthalenes studied and approximately $6.0 \%$ of all $\mathrm{C}_{2}$ alkylphenanthrenes present in diesel fuel. In contrast, $10 \%$ ethanol addition to diesel fuel resulted in the elution of more than $80 \%$ of each of the studied trimethylnaphthalene peaks and more than $70 \%$ of each of the studied $C_{2}$ alkylphenanthrene peaks present in diesel fuel (Table 1).

Similar to the results of this study, previous researchers have shown that increasing ethanol content from $5 \%$ to $10 \%$ results in considerable increase in the solubility of petroleum hydrocarbons in aqueous layers [9,11,35]. Ethanol-induced co-solvency is evidently responsible for the increased leaching potentials of these hydrocarbons [36]. In addition, ethanol breaks the surface tension of water-hydrocarbon mixtures, enhancing hydrocarbon solubility and thereby increasing their leaching potentials through the soil matrix. This portends significant health and environmental dangers, considering the toxicity of polycyclic aromatic hydrocarbons.

\subsection{Implications for Groundwater Quality and Exposure Mechanisms}

Our results provide clear evidence that ethanol addition to diesel fuel directly affects the leaching potentials of PAHs. Although this study focused on bicyclic, tricyclic, and tetracyclic aromatic hydrocarbons, its results agree with previous work on BTEX compounds [11,15], $n$-alkanes [30], and naphthalene [9].

The result of this study portends considerable negative impacts on groundwater quality and human health. Like the predecessor oxygen-containing organic compound (MTBE) that was added to gasoline, the negative effects of ethanol-blended fuels on groundwater may not be immediately apparent. Oil companies in the USA supported the use of MTBE until 1997 when Tosco, the then largest independent oil refiner in the USA, asked the Californian Air Resources Board for authorization to move away from MTBE use, as extensive contamination would result in huge costs to restore the state's drinking water [36,37]. Eventually, various sets of legislation in the USA successfully phased out MTBE and introduced ethanol as an alternative oxygenate. However, in view of the potential of ethanol to enhance the leaching potentials of carcinogenic and mutagenic hydrocarbons into groundwater, this innovation is far from being the panacea.

As shown by our results, ethanol serves as a co-solvent between hydrophobic contaminants and water, leading to improved solubility and migration into surface waters and groundwater. This process therefore increases the risk of human exposure to potential carcinogens and mutagens. 
(a)

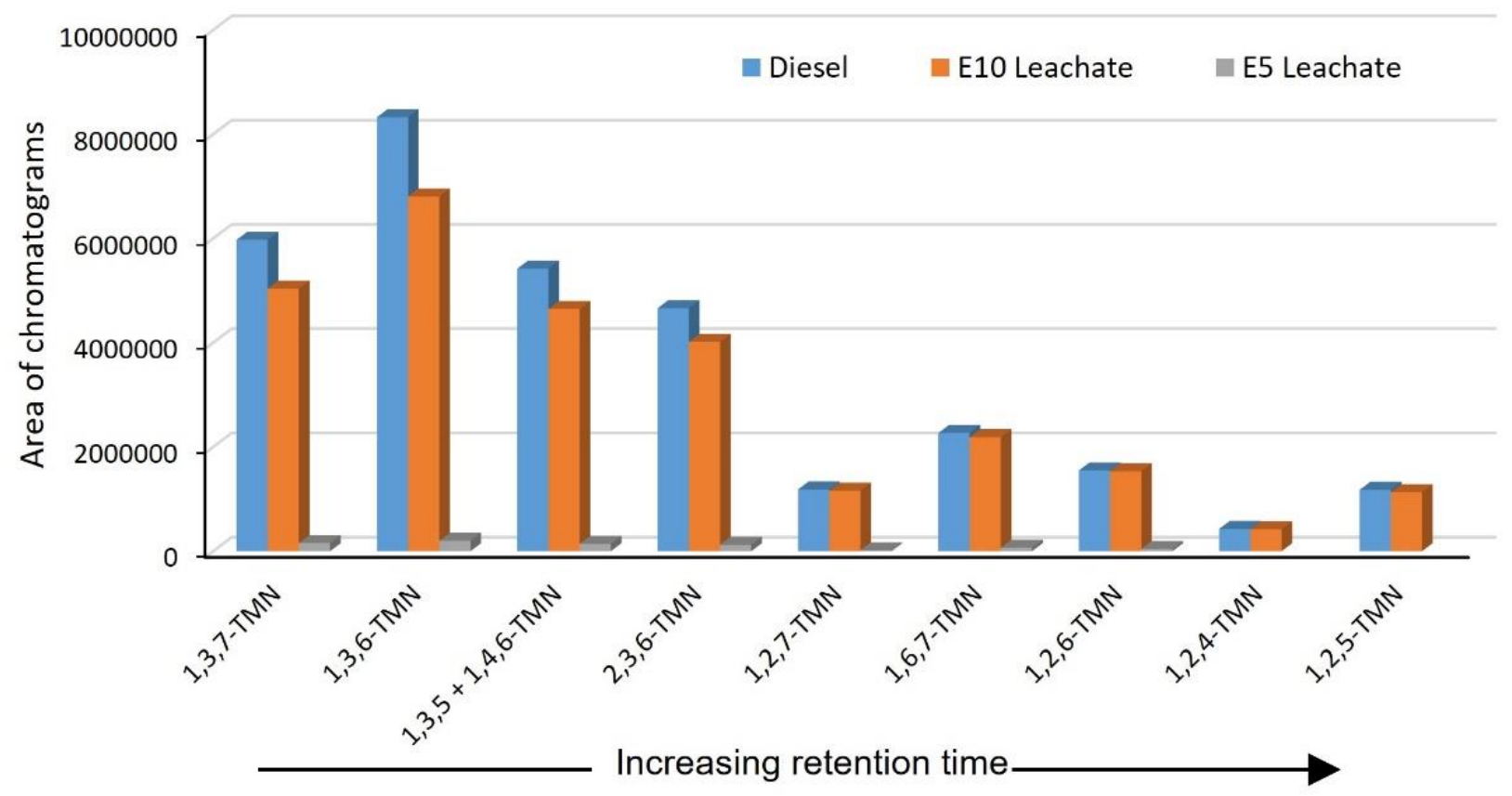

(b)

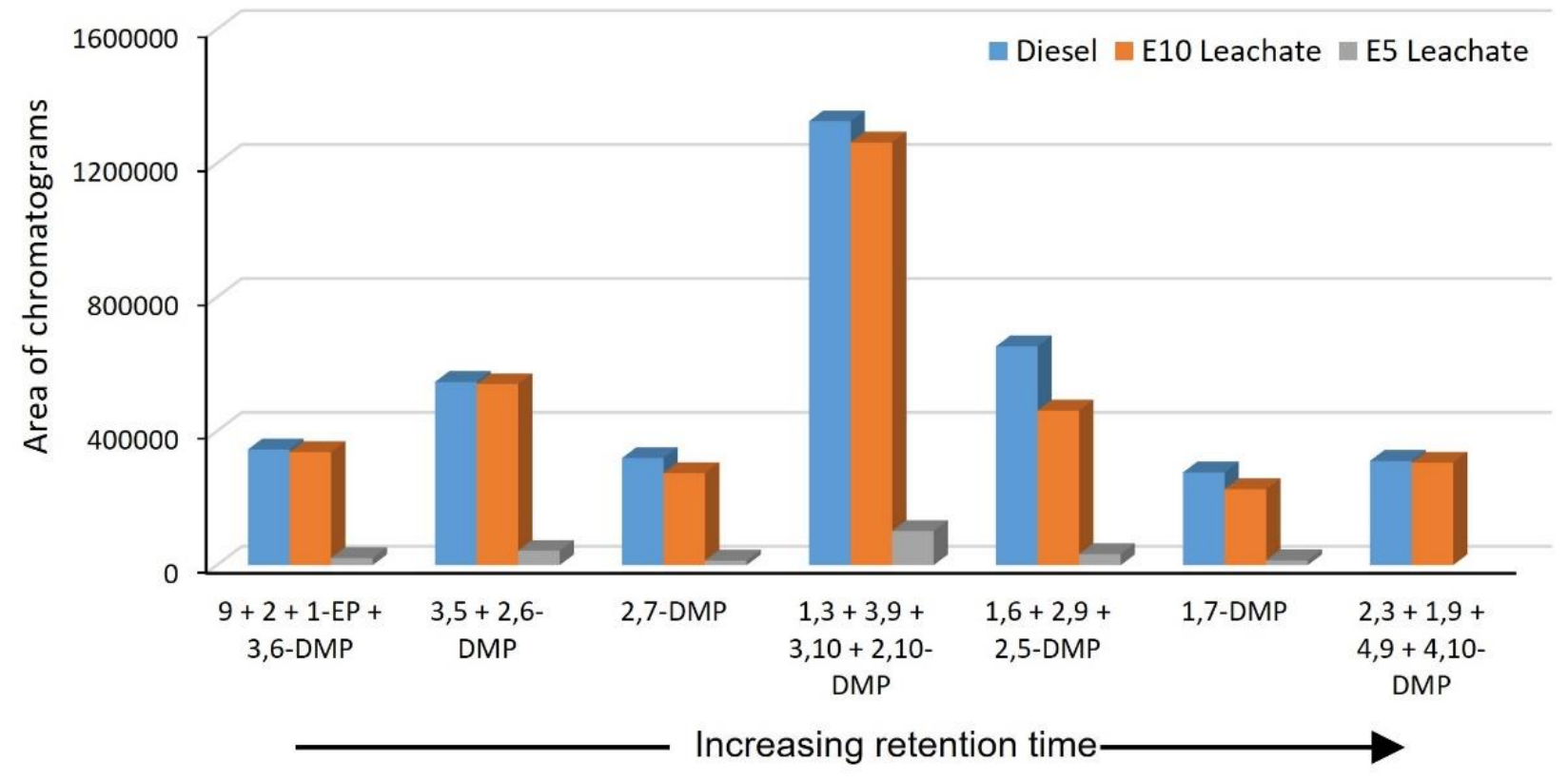

Figure 2. Comparison of the amount of (a) trimethylnaphthalenes (TMN) and (b) dimethylphenanthrenes (DMP) and ethylphenanthrenes (EP) in diesel fuel, with the amount eluted by $10 \%$ and $5 \%$ ethanol addition in the E10 and E5 leachates. 
Table 1. The amount of trimethylnaphthalenes and $C_{2}$ alkylphenanthrenes eluted by $5 \%$ ethanol addition (E5) and 10\% ethanol addition (E10) as percentages of these compounds present in diesel fuel.

\begin{tabular}{|c|c|c|c|c|c|}
\hline Trimethylnaphthalenes & E5 & E10 & $\mathrm{C}_{2}$ Alkylphenanthrenes & E5 & E10 \\
\hline $1,3,7-\mathrm{TMN}$ & 2.6 & 84.3 & $9+2+1-\mathrm{EP}+3,6-\mathrm{DMP}$ & 6.2 & 97.7 \\
\hline $1,3,6-\mathrm{TMN}$ & 2.4 & 81.7 & $3,5+2,6-\mathrm{DMP}$ & 7.7 & 98.7 \\
\hline $1,3,5+1,4,6-\mathrm{TMN}$ & 2.6 & 85.7 & 2,7-DMP & 4.3 & 86.0 \\
\hline 2,3,6-TMN & 2.6 & 86.1 & $1,3+3,9+3,10+2,10-\mathrm{DMP}$ & 7.6 & 95.2 \\
\hline $1,2,7-\mathrm{TMN}$ & 1.5 & 98.1 & $1,6+2,9+2,5-\mathrm{DMP}$ & 5.1 & 70.7 \\
\hline $1,6,7-\mathrm{TMN}$ & 2.9 & 96.4 & 1,7-DMP & 5.2 & 81.9 \\
\hline $1,2,6-\mathrm{TMN}$ & 2.7 & 99.0 & $2,3+1,9+4,9+4,10-\mathrm{DMP}$ & ND & 98.3 \\
\hline $1,2,4-\mathrm{TMN}$ & ND & 97.8 & & & \\
\hline $1,2,5-\mathrm{TMN}$ & ND & 96.3 & & & \\
\hline
\end{tabular}

TMN: trimethylnaphthalene; EP: ethylphenanthrene; DMP: dimethylphenanthrene; ND: not detected.

\section{Conclusions}

Petroleum oxygenates such as ethanol are added to fossil fuels in order to reduce $\mathrm{CO}_{2}$ and particulate matter emission. This study, however, has shown that ethanol enhances the leaching potentials of PAHs, with $10 \%$ ethanol addition to diesel significantly increasing the amounts of elution of trimethylnaphthalenes, $C_{2}$ alkylphenanthrenes (such as dimethylphenanthrenes and ethylphenanthrenes), and methylpyrenes. This increases the risk of both groundwater contamination and human exposure. This will be especially the case with the more common ethanol-gasoline mixtures, owing to the higher abundance of constituents of lower molecular weight (and more aqueous soluble) aromatic hydrocarbons such as benzene, alkylbenzenes, and naphthalenes in gasoline. In view of the toxicity and environmental persistence of the high molecular weight PAHs examined in this study, coupled with the prevalence of groundwater contamination, it is imperative for energy scientists to carefully consider the environmental impacts of ethanol-blended innovations holistically.

Author Contributions: Conceptualization, M.O.E. and S.C.G.; methodology, M.O.E. and S.C.G.; software, S.C.G.; validation, M.O.E. and S.C.G.; formal analysis, M.O.E. and S.C.G.; investigation, M.O.E. and S.C.G.; resources, M.O.E. and S.C.G.; data curation, M.O.E. and S.C.G.; writing—original draft preparation, M.O.E.; writing-review and editing, S.C.G.; visualization, M.O.E. and S.C.G.; supervision, S.C.G.; project administration, M.O.E. and S.C.G.; funding acquisition, M.O.E. All authors have read and agreed to the published version of the manuscript.

Funding: This research was funded by the Commonwealth Government of Australia, grant number 2017561, and the APC was funded by the Open Access Grant Program of the German Research Foundation (DFG) and the Open Access Publication Fund of the University of Goettingen.

Institutional Review Board Statement: Not applicable.

Informed Consent Statement: Not applicable.

Data Availability Statement: The data presented in this study are available within the article.

Acknowledgments: The authors would like to thank the Commonwealth Government of Australia for supporting this research project by providing M.O.E. with an international Research Training Program (iRTP) Scholarship (Allocation Numbers: 2017561). This publication was supported financially by the Open Access Grant Program of the German Research Foundation (DFG) and the Open Access Publication Fund of the University of Goettingen, for which the authors are very grateful.

Conflicts of Interest: The authors declare no conflict of interest. The funders had no role in the design of the study; in the collection, analyses, or interpretation of data; in the writing of the manuscript; or in the decision to publish the results. 


\section{References}

1. USA Goverment. 42 U.S. Code. In Air Pollution Prevention and Control; United States Government: Washington, DC, USA, 2013; Chapter 85.

2. RFA. Accelerating Industry Innovation: 2012 Ethanol Industry Outlook; Renewable Fuels Association: St. Louis, MO, USA, 2012.

3. Stephanes, R. Ordinance No. 143 of 27 June 2007; Ministry of Agriculture, Livestock and Supply: Brasilia, Brazil, 2007.

4. Cassuto, D.N.; Gueiros, C.; Cassuto, D.N.; Gueiros, C. The Evolution of the Brazilian Regulation of Ethanol and Possible Lessons for the United States. Wis. Int. Law J. 2013, 30, 477.

5. Oddone, D.; Amaral, A.; Kury, F.; Cecchi, J.C.; Amorelli, D. Fuel Production and Supply Opportunities in Brazil; National Agency of Petroleum, Natural Gas and Biofuels: Rio de Janeiro, Brazil, 2017.

6. Inal, F.; Senkan, S.M. Effects of oxygenate additives on polycyclic aromatic hydrocarbons(pahs) and soot formation. Combust. Sci. Technol. 2002, 174, 1-19. [CrossRef]

7. Golea, D.; Rezgui, Y.; Guemini, M.; Hamdane, S. Reduction of PAH and Soot Precursors in Benzene Flames by Addition of Ethanol. J. Phys. Chem. A 2012, 116, 3625-3642. [CrossRef] [PubMed]

8. Dandajeh, A.H.; Talibi, M.; Ladommatos, N.; Hellier, P. Influence of Combustion Characteristics and Fuel Composition on Exhaust PAHs in a Compression Ignition Engine. Energies 2019, 12, 2575. [CrossRef]

9. Corseuil, H.X.; Kaipper, B.I.A.; Fernandes, M. Cosolvency effect in subsurface systems contaminated with petroleum hydrocarbons and ethanol. Water Res. 2004, 38, 1449-1456. [CrossRef]

10. Alvarez, P.J.; Hunt, C.S. The effect of fuel alcohol on monoaromatic hydrocarbon biodegradation and natural attenuation. Rev. Latinoam. Microbiol. 2002, 44, 83-104.

11. Powers, S.E.; Hunt, C.S.; Heermann, S.E.; Corseuil, H.X.; Rice, D.; Alvarez, P.J.J. The transport and fate of ethanol and BTEX in groundwater contaminated by gasohol. Crit. Rev. Environ. Sci. Technol. 2001, 31, 79-123. [CrossRef]

12. Lovanh, N.; Hunt, C.S.; Alvarez, P.J.J. Effect of ethanol on BTEX biodegradation kinetics: Aerobic continuous culture experiments. Water Res. 2002, 36, 3739-3746. [CrossRef]

13. Snape, I.; Harvey, P.M.; Ferguson, S.H.; Rayner, J.L.; Revill, A.T. Investigation of evaporation and biodegradation of fuel spills in Antarctica I. A chemical approach using GC-FID. Chemosphere 2005, 61, 1485-1494. [CrossRef]

14. Wang, Z.; Fingas, M.; Blenkinsopp, S.; Sergy, G.; Landriault, M.; Sigouin, L.; Foght, J.; Semple, K.; Westlake, D.W.S. Comparison of oil composition changes due to biodegradation and physical weathering in different oils. J. Chromatogr. A 1998, 809, 89-107. [CrossRef]

15. Freitas, J.G.; Mocanu, M.T.; Zoby, J.L.G.; Molson, J.W.; Barker, J.F. Migration and fate of ethanol-enhanced gasoline in groundwater: A modelling analysis of a field experiment. J. Contam. Hydrol. 2011, 119, 25-43. [CrossRef] [PubMed]

16. Duffy, J.J.; Peake, E.; Mohtadi, M.F. Oil spills on land as potential sources of groundwater contamination. Environ. Int. 1980, 3, 107-120. [CrossRef]

17. Ugochukwu, U.C.; Ochonogor, A. Groundwater contamination by polycyclic aromatic hydrocarbon due to diesel spill from a telecom base station in a Nigerian City: Assessment of human health risk exposure. Environ. Monit. Assess. 2018, $190,249$. [CrossRef] [PubMed]

18. Brindha, K.; Elango, L. PAHs contamination in groundwater from a part of metropolitan city, India: A study based on sampling over a 10-year period. Environ. Earth Sci. 2014, 71, 5113-5120. [CrossRef]

19. Ndimele, P.E.; Saba, A.O.; Ojo, D.O.; Ndimele, C.C.; Anetekhai, M.A.; Erondu, E.S. Remediation of Crude Oil Spillage. In The Political Ecology of Oil and Gas Activities in the Nigerian Aquatic Ecosystem; Ndimele, P.E., Ed.; Academic Press: Cambridge, MA, USA, 2018; Chapter 24; pp. 369-384. [CrossRef]

20. IARC. Some Traditional Herbal Medicines, Some Mycotoxins, Naphthalene and Styrene. In IARC Monographs on the Evaluation of Carcinogenic Risks to Humans; International Agency for Research on Cancer: Lyon, France, 2002; Volume 82.

21. IARC. Overall Evaluations of Carcinogenicity: An Updating of IARC Monographs Volumes 1 to 42 . In IARC Monographs on the Evaluation of the Carcinogenic Risks to Humans; International Agency for Research on Cancer: Lyon, France, 1987 ; Supplement 7.

22. Jeffrey Lewis, R. Naphthalene animal carcinogenicity and human relevancy: Overview of industries with naphthalene-containing streams. Regul. Toxicol. Pharmacol. 2012, 62, 131-137. [CrossRef]

23. LaVoie, E.J.; Bedenko, V.; Tulley-Freller, L.; Hoffmann, D. Tumor-initiating activity and metabolism of polymethylated phenanthrenes. Cancer Res. 1982, 42, 4045.

24. Engst, W.; Landsiedel, R.; Hermersdörfer, H.; Doehmer, J.; Glatt, H. Benzylic hydroxylation of 1-methylpyrene and 1-ethylpyrene by human and rat cytochromes P450 individually expressed in V79 Chinese hamster cells. Carcinogenesis 1999, 20, 1777-1785. [CrossRef]

25. Bendadani, C.; Meinl, W.; Monien, B.H.; Dobbernack, G.; Glatt, H. The carcinogen 1-methylpyrene forms benzylic DNA adducts in mouse and rat tissues in vivo via a reactive sulphuric acid ester. Arch. Toxicol. 2014, 88, 815-821. [CrossRef]

26. Bendadani, C.; Steinhauser, L.; Albert, K.; Glatt, H.; Monien, B.H. Metabolism and excretion of 1-hydroxymethylpyrene, the proximate metabolite of the carcinogen 1-methylpyrene, in rats. Toxicology 2016, 366-367, 43-52. [CrossRef]

27. Margitfalvi, J.L.; Gőbölös, S.; Tálas, E.; Borbáth, I. 33-Modification of Pt-Re/A12O3 Naphtha Reforming Catalysts by Tin Tetraethyl Using Controlled Surface Reaction to Reduce the Yield of Benzene and Aromatics. In Studies in Surface Science and Catalysis; Eguchi, K., Machida, M., Yamanaka, I., Eds.; Elsevier: Amsterdam, The Netherlands, 2007; Volume 172, pp. 177-180. 
28. Corma, A.; Martínez, A. Zeolites in Refining and Petrochemistry. In Studies in Surface Science and Catalysis; Ĉejka, J., van Bekkum, H., Eds.; Elsevier: Amsterdam, The Netherlands, 2005; Volume 157, pp. 337-366.

29. Moreno, J.A.; Poncelet, G. n-Butane Isomerization over Al-Promoted Sulfated Zirconias. Influence of the Sulfate Content. In Studies in Surface Science and Catalysis; Gaigneaux, E., De Vos, D.E., Grange, P., Jacobs, P.A., Martens, J.A., Ruiz, P., Poncelet, G., Eds.; Elsevier: Amsterdam, The Netherlands, 2000; Volume 143, pp. 1003-1010.

30. Eze, M.O.; George, S.C. Ethanol-blended petroleum fuels: Implications of co-solvency for phytotechnologies. RSC Adv. 2020, 10, 6473-6481. [CrossRef]

31. USEPA. Separatory Funnel Liquid-Liquid Extraction; Method 3510C; United States Environmental Protection Agency: Washington, DC, USA, 1996.

32. Al-Baldawi, I.A.; Abdullah, S.R.S.; Anuar, N.; Suja, F.; Mushrifah, I. Phytodegradation of total petroleum hydrocarbon (TPH) in diesel-contaminated water using Scirpus grossus. Ecol. Eng. 2015, 74, 463-473. [CrossRef]

33. USEPA. Semivolatile Organic Compounds by GC/MS; Method 8270D; United States Environmental Protection Agency: Washington, DC, USA, 1998.

34. Flannery, E.N.; George, S.C. Assessing the syngeneity and indigeneity of hydrocarbons in the $1.4 \mathrm{Ga}$ Velkerri Formation, McArthur Basin, using slice experiments. Org. Geochem. 2014, 77, 115-125. [CrossRef]

35. Gerdes, K.R.; Suppes, G.J. Miscibility of Ethanol in Diesel Fuels. Ind. Eng. Chem. Res. 2001, 40, 949-956. [CrossRef]

36. Adam, G.; Gamoh, K.; Morris, D.G.; Duncan, H. Effect of alcohol addition on the movement of petroleum hydrocarbon fuels in soil. Sci. Total Environ. 2002, 286, 15-25. [CrossRef]

37. McCarthy, J.E.; Tiemann, M. MTBE in Gasoline: Clean Air and Drinking Water Issues; Congressional Research Service, The Library of Congress: Washington, DC, USA, 2004; Available online: https://digitalcommons.unl.edu/crsdocs/26/ (accessed on 4 February 2022). 